\title{
17: 31649843-31647955
}

National Cancer Institute

\section{Source}

National Cancer Institute. 17: 31649843-31647955. NCI Thesaurus. Code C41874.

Physical location of CCL3L1_Gene 